Article

\title{
Degradation of Polysaccharides from Grateloupia filicina and Their Antiviral Activity to Avian Leucosis Virus Subgroup J
}

\author{
Yuhao Sun ${ }^{1,2,3}$ (D), Xiaolin Chen ${ }^{1,3, *}$, Ziqiang Cheng ${ }^{4}$, Song Liu ${ }^{1,3}$, Huahua Yu ${ }^{1,3}$, \\ Xueqin Wang ${ }^{1,3}$ and Pengcheng $\mathrm{Li}^{1,3, *}$ \\ 1 Key Laboratory of Experimental Marine Biology, Institute of Oceanology, Chinese Academy of Sciences, \\ No. 7 Nanhai Road, Qingdao 266071, China; 18669884128@163.com (Y.S.); sliu@qdio.ac.cn (S.L.); \\ yuhuahua@qdio.ac.cn (H.Y.); xueqinwang@qdio.ac.cn (X.W.) \\ 2 University of Chinese Academy of Sciences, Beijing 100049, China \\ 3 Laboratory for Marine Drugs and Bioproducts of Qingdao National Laboratory for Marine Science and \\ Technology, No. 7 Nanhai Road, Qingdao 266071, China \\ 4 College of Animal Science and Veterinary Medicine, Shandong Agricultural University, \\ No. 61 Daizong Road, Taian 271018, China; czqsd@126.com \\ * Correspondence: chenxl@qdio.ac.cn (X.C.); pcli@qdio.ac.cn (P.L.); Tel.: +86-0532-8289-8707 (X.C. \& P.L.)
}

Received: 18 September 2017; Accepted: 1 November 2017; Published: 3 November 2017

\begin{abstract}
In this study, polysaccharides from Grateloupia filicinia (GFP) were extracted and several low molecular weight $(\mathrm{Mw})$ G. filicina polysaccharides (LGFPs) were prepared by the hydrogen peroxide $\left(\mathrm{H}_{2} \mathrm{O}_{2}\right)$ oxidation method. Additionally, the effect of different experimental conditions on the degradation of GFP was determined. Results showed that the GFP degradation rate was positively related to $\mathrm{H}_{2} \mathrm{O}_{2}$ concentration and temperature, and negatively related to $\mathrm{pH}$. Chemical analysis and Fourier transform infrared spectra (FT-IR) of GFP and LGFPs showed that the degradation caused a slight decrease of total sugar and sulfate content. However, there was no obvious change for monosaccharide contents. Then, the anti-ALV-J activity of GFP and LGFPs were determined in vitro. Results revealed that all of the samples could significantly inhibit ALV-J and lower Mw LGFPs exhibited a stronger suppression, and that the fraction LGFP-3 with Mw $8.7 \mathrm{kDa}$ had the best effect. In addition, the reaction phase assays showed that the inhibition effect was mainly because of the blocking virus adsorption to host cells. Moreover, real-time PCR, western-blot, and IFA were further applied to evaluate the blocking effects of LGFP-3. Results showed that the gene relative expression and gp85 protein for LGFPS-3 groups were all reduced. Data from IFA showed that there was less virus infected cells for 1000 and $200 \mu \mathrm{g} / \mathrm{mL}$ LGFPS-3 groups when compared to virus control. Therefore, lower Mw polysaccharides from G. filicina might supply a good choice for ALV-J prevention and treatment.
\end{abstract}

Keywords: Grateloupia filicina; degradation; low molecular weight polysaccharides; antiviral activity; ALV-J

\section{Introduction}

Avian leucosis virus subgroup J (ALV-J) is an immunosuppressive virus, which generally causes a diversity of tumors, such as hemangioma and myeloid leucosis in birds [1]. It has spread worldwide since the first time it was discovered in British broiler breeds in 1988. In China, ALV-J was first detected and officially recorded in 1999 [2], and after that the ALV-J infection appeared around the country. The virus could infect chickens through both horizontal and vertical transmission; initially it was mainly found in turkeys and broilers, but recently it also brought disease and death in egg layers 
and broiler breeders [3], which caused heavy losses to the poultry breeding industry. Due to the complex genetic sequence and the antigenic variability, there are still no commercial vaccines against ALV-J infection [4-6]. Currently, the only way to prevent ALV-J is by quarantining and eliminating positive chickens. Therefore, it is urgent and necessary to find effective antiviral medicine to control ALV-J spread.

On the other hand, the red seaweed genus Grateloupia, which belongs to Halymeniaceae, is an intertidal alga [7], which is widely distributed in the countries of the west Pacific bank such as China, Japan, and South Korea. It has enormous commercial value because it may be used as raw materials for carrageenan. In addition, the protein content of Grateloupia turuturu can account for $20 \%$ of the dry weight therefore being of potential in the food industry [8]. Polysaccharide is another important chemical compound of Grateloupia. It has attracted wide attention in recent years due to its multiple biological activities. For example, Nikapitiya et al. reported a good anticoagulant activity of a sulfated polysaccharide that is extracted from Grateloupia filicina [9]. In addition, Yu et al. isolated an agaran-type polysaccharide from G. filicina and demonstrated that the polysaccharide carried antiangiogenic effects [10]. Further, the polysaccharides that are extracted from G. livida were reported to have antioxidant, antibacterial, and antisachistosomal activity [11,12]. Scientists also studied the antiviral activity of Grateloupia and found that polysaccharides obtained from G. indica, G. filicina, and G. longilia had anti-HSV-1, HSV-2, HIV-1, and dengue virus activity $[13,14]$. However, the studies on antiviral activity of the polysaccharide from Grateloupia were mainly focused on human suffering virus, and few studies aimed at finding the effects against poultry viruses.

Even though the high Mw Grateloupia polysaccharide has various biological activities, its huge Mw causes low solubility and tough organism absorption, which greatly restricts its application. Commonly, lower Mw algal polysaccharides are obtained by the degradation of high $\mathrm{Mw}$ polysaccharides. When compared with original high $\mathrm{Mw}$ polysaccharide, low Mw polymers are characterized by having a higher water solubility and stability, and easy organism absorption [15]. In order to obtain lower Mw polysaccharide a chain of polysaccharides is usually broken, as according to the $1 \rightarrow 3,1 \rightarrow 4$ and $1 \rightarrow 6$ glycosidic linkages fractures, and some of their original activity might be improved in different degrees [16-18]. Additionally, in recent years, it has been found that low Mw polysaccharides from seaweeds presented some effects on the suppression H1N1 influenza virus and HIV [19-22]. However, research on the anti-ALV-J activity of algal polysaccharides still scarce. Therefore, it would be innovative and promising applying the low Mw polysaccharide from Grateloupia to prevent ALV-J.

In this study, polysaccharides from G. filicina (GFP) were extracted by hot water extraction and were degraded via $\mathrm{H}_{2} \mathrm{O}_{2}$ oxidative degradation. The effect of different conditions (including concentration of $\mathrm{H}_{2} \mathrm{O}_{2}, \mathrm{pH}$ and temperature) on the degradation of GFP was determined. Several low Mw fractions of GFP (LGFPs) were prepared and their chemical composition was tested. Finally, the anti-ALV-J activity of LGFPs was explored. The results of this study would provide a possible useful application of seaweeds polysaccharides as a veterinary medicine in the prevention of ALV-J.

\section{Results}

\subsection{Influence of Degradation Conditions on the Mws of Polysaccharides}

The yield of the GFP that was extracted by traditional hot water extraction and alcohol precipitation methods was $34.44 \%$. Freeze-dried GFP was dissolved in distilled water and degraded by $\mathrm{H}_{2} \mathrm{O}_{2}$ oxidative method. The influence of different conditions on the degradation of GFP was determined.

\subsubsection{Effect of Temperature}

In order to investigate the effect of temperature on the Mw of GFP, $60{ }^{\circ} \mathrm{C}, 70{ }^{\circ} \mathrm{C}, 80^{\circ} \mathrm{C}, 90{ }^{\circ} \mathrm{C}$, and $100{ }^{\circ} \mathrm{C}$ were selected. As shown in Figure 1, the $\mathrm{Mw}$ of the products was high at a comparatively low temperature (such as $60^{\circ} \mathrm{C}$ and $70{ }^{\circ} \mathrm{C}$ ). At $120 \mathrm{~min}$, the Mws changed to $76.9 \mathrm{kDa}, 36 \mathrm{kDa}$ and 
$18 \mathrm{kDa}$ for $60^{\circ} \mathrm{C}, 70^{\circ} \mathrm{C}$, and $80^{\circ} \mathrm{C}$, respectively. On the contrary, the Mws could violently decrease to $3.2 \mathrm{kDa}$ and $2.2 \mathrm{kDa}$ in $60 \mathrm{~min}$ when temperatures were $90^{\circ} \mathrm{C}$ and $100^{\circ} \mathrm{C}$ and the curves were tend to stay after $120 \mathrm{~min}$. At last, the Mws of the polysaccharides for $60^{\circ} \mathrm{C}, 70^{\circ} \mathrm{C}, 80^{\circ} \mathrm{C}, 90^{\circ} \mathrm{C}$, and $100^{\circ} \mathrm{C}$ groups were $63 \mathrm{kDa}, 16 \mathrm{kDa}, 5.7 \mathrm{kDa}, 2.0 \mathrm{kDa}$, and $1.8 \mathrm{kDa}$, respectively. The results showed that high temperature was more favorable for degradation and feasible to generate lower Mws polysaccharides.

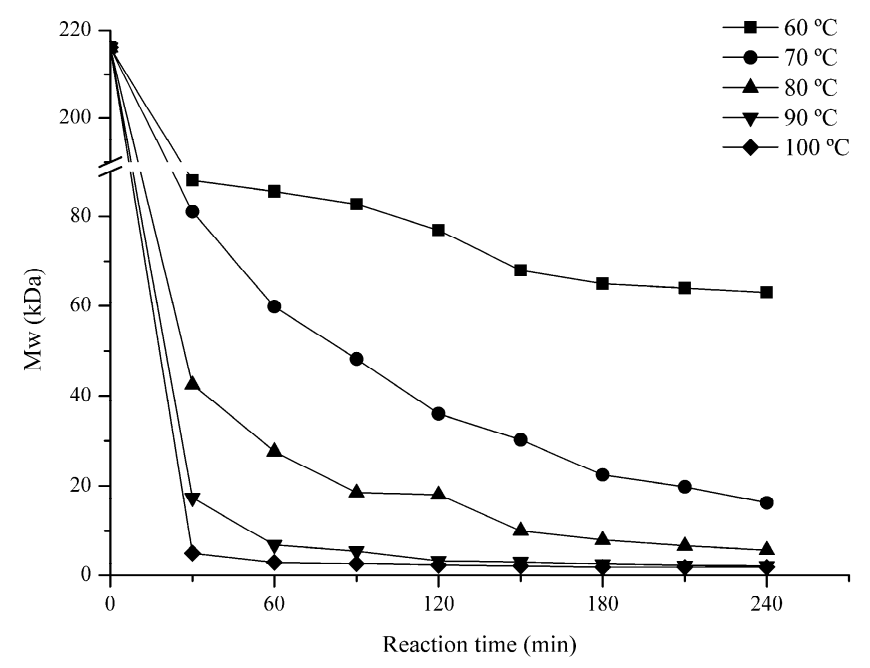

Figure 1. Effects of temperature on the molecular weight $(\mathrm{Mw})$ of Grateloupia filicinia polysaccharide (GFP). The reaction was carried out in $\mathrm{pH} 1$ and $0.15 \% \mathrm{H}_{2} \mathrm{O}_{2}$ under different temperature conditions.

\subsubsection{Effect of $\mathrm{H}_{2} \mathrm{O}_{2}$ Concentration}

Figure 2 shows the effect of $\mathrm{H}_{2} \mathrm{O}_{2}$ concentration $(0.03 \%, 0.15 \%, 0.30 \%, 0.6 \%$, and $1.5 \%)$ on the $\mathrm{Mw}$ of the polysaccharides. In the first $60 \mathrm{~min}, \mathrm{Mw}$ of $0.03 \%$ and $0.15 \%$ concentrations degradation products were similar and was bigger than the other groups, it decreased to about $9.5 \mathrm{kDa}$ after $60 \mathrm{~min}$. By contrast, the reaction with $0.3 \%, 0.6 \%$, and $1.5 \%$ concentration groups presented no differences and were faster; the $\mathrm{Mw}$ of the products were all about $6.7 \mathrm{kDa}$ after $60 \mathrm{~min}$. However, after $90 \mathrm{~min}$, the degradation results were similar for all of the groups. The curves of all $\mathrm{H}_{2} \mathrm{O}_{2}$ concentrations were closer, and the $\mathrm{Mw}$ of the final low molecular weight $(\mathrm{LMw})$ polysaccharides were all around $2 \mathrm{kDa}$.

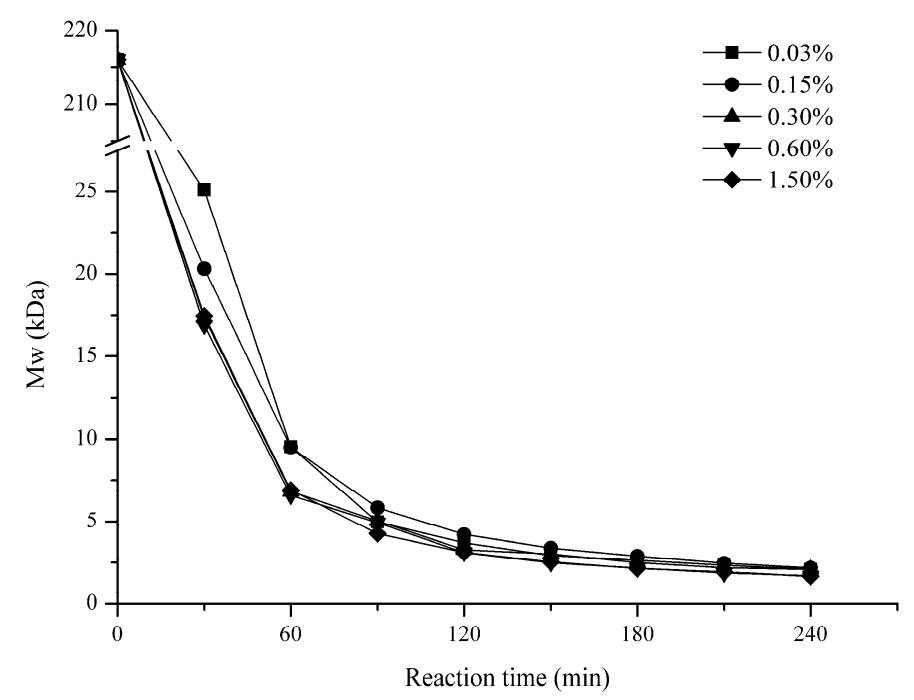

Figure 2. Effect of $\mathrm{H}_{2} \mathrm{O}_{2}$ concentration on the Mw of GFP. GFP was degraded at $\mathrm{pH} 1$ and $90{ }^{\circ} \mathrm{C}$ under different $\mathrm{H}_{2} \mathrm{O}_{2}$ concentration conditions. 


\subsubsection{Effect of $\mathrm{pH}$}

Figure 3 illustrates the $\mathrm{pH}$ impact on the degradation of GFP. ( $\mathrm{pH} 1,2,3,4$, and 8) were tested. As shown in Figure 3, the $\mathrm{pH}$ had a significant influence on GFP degradation. In $30 \mathrm{~min}$, the Mw were remarkably reduced to $20 \mathrm{kDa}$ and $54 \mathrm{kDa}$ when under the lowest $\mathrm{pH} 1$ and 2, respectively; but when $\mathrm{pH}$ was increased to 3, 4, or 8, the Mw of GFP were approximately $120 \mathrm{kDa}$ at $30 \mathrm{~min}$. After $120 \mathrm{~min}$, the $\mathrm{Mw}$ of GFP changed slightly to a final $\mathrm{Mw}$ of $2.1 \mathrm{kDa}$ and $3.2 \mathrm{kDa}$ for $\mathrm{pH} 1$ and 2, respectively. However, when the $\mathrm{pH}$ increased to 3, 4, or 8, the Mw decreased drastically to $4.2 \mathrm{kDa}, 4.5 \mathrm{kDa}$ and $7.6 \mathrm{kDa}$ at $240 \mathrm{~min}$, respectively. This suggested that the higher $\mathrm{pH}$ (such as 3,4 , and 8 ) could also degrade GFP, but a lower $\mathrm{pH}$ would accelerate the reaction to a shorter time.

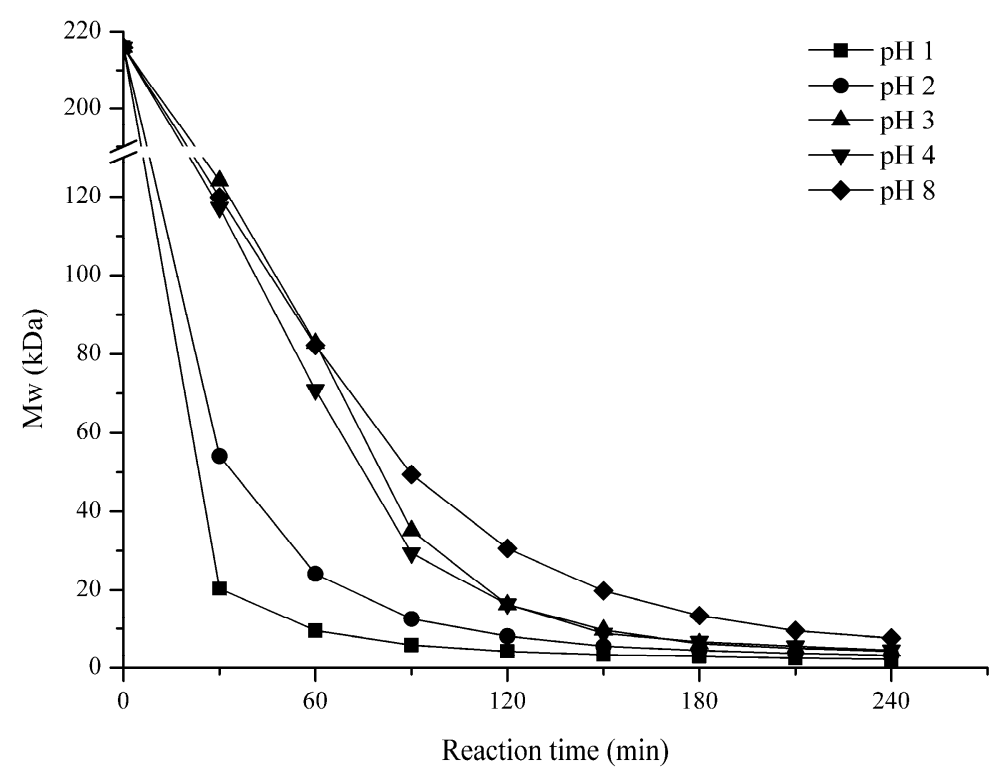

Figure 3. Effects of $\mathrm{pH}$ on the $\mathrm{Mw}$ of GFP. GFP was degraded in $0.3 \% \mathrm{H}_{2} \mathrm{O}_{2}$ at $90{ }^{\circ} \mathrm{C}$ under different $\mathrm{pH}$ conditions.

\subsection{Preparation and Chemical Characterization of LGFP}

\subsubsection{Preparation of LGFP}

Depending on the influence of different conditions on the degradation of GFP, a series of conditions were screened to prepare four kinds of LGFP solutions. After being neutralized to $\mathrm{pH} 7$, the solution was dialyzed against tap water for $24 \mathrm{~h}$ and was then changed to distilled water for $24 \mathrm{~h}$. The dialysis tube for LGFP-1 to LGFP-4 were $10 \mathrm{kDa}, 3.5 \mathrm{kDa}, 1 \mathrm{kDa}$, and $0.5 \mathrm{kDa} \mathrm{Mw}$ cut off, respectively. After dialysis, the solutions were filtered by common filter paper, freeze dried, and then the yield was calculated. The specific preparation conditions and yield are shown in Table 1.

Table 1. Preparation conditions and yield of LGFPs.

\begin{tabular}{cccccc}
\hline Sample & Temperature $\left({ }^{\circ} \mathbf{C}\right)$ & $\mathbf{p H}$ & $\mathbf{H}_{\mathbf{2}} \mathbf{O}_{\mathbf{2}}(\mathbf{\%})$ & Time (min) & Yield (\%) \\
\hline LGFP-1 & 90 & 4 & 0.3 & 75 & 73.4 \\
LGFP-2 & 90 & 4 & 0.3 & 135 & 46.28 \\
LGFP-3 & 90 & 4 & 0.3 & 210 & 42.99 \\
LGFP-4 & 90 & 4 & 0.3 & 240 & 40.38 \\
\hline
\end{tabular}

\subsubsection{Chemical Characterization}

According to the conditions exhibited in Table 1, four LGFPs with different Mw were prepared. The HPLC profiles and chemical composition of the initial GFP and the LGFPs are given in Figure 4 
and Table 2. The HPLC standard curve equation was $y=-2.4616 x+24.507$ with the Log Mw as the abscissa and elution time as the ordinate. The $R$ square was 0.991 . With the decrease of $\mathrm{Mw}$ of the polysaccharides, the total sugar content has decreased as well, but the sulfate content decreased slightly. The protein content of LGFPs also reduced. Results of monosaccharide composition showed that all samples were mainly composed of galactose.

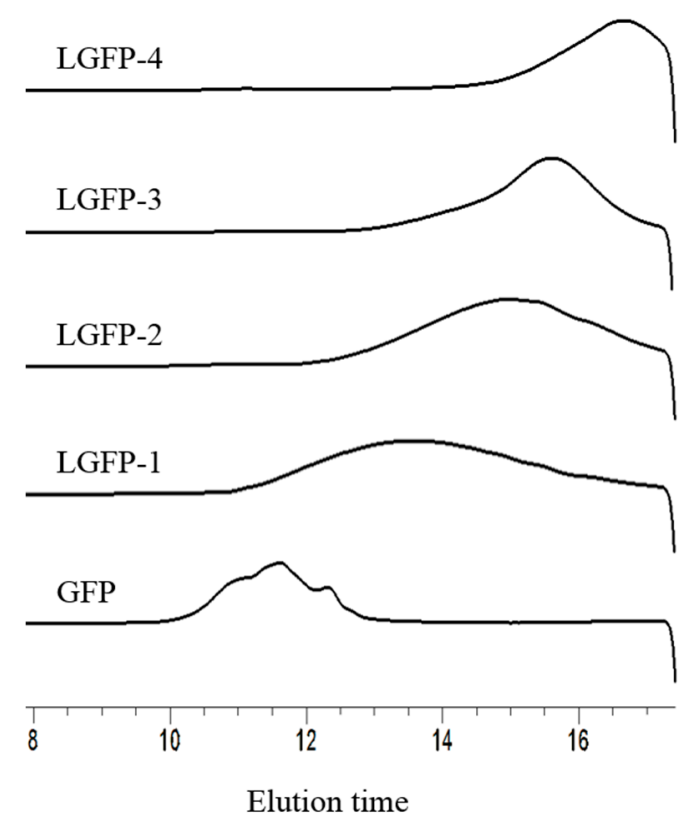

Figure 4. HPLC profiles of the GFP and LGFPs.

Table 2. Chemical composition of polysaccharides ( $\% w / w$ of dry weight).

\begin{tabular}{|c|c|c|c|c|c|c|c|c|c|c|c|}
\hline \multirow{2}{*}{ Sample } & \multirow{2}{*}{ Total Sugar (\%) } & \multirow{2}{*}{ Sulfate $(\%)$} & \multirow{2}{*}{ Protein $(\%)$} & \multirow{2}{*}{ Mw (kDa) } & \multicolumn{7}{|c|}{ Monosaccharides Composition (Molar Ratio) } \\
\hline & & & & & Man & Rha & Glc A & Glc & Gal & Xyl & Fuc \\
\hline GFP & $55.22 \pm 0.96$ & $21.52 \pm 0.04$ & $1.45 \pm 0.08$ & $216.7 \pm 1.2$ & 0.00 & 0.01 & 0.03 & 0.01 & 1 & 0.03 & 0.03 \\
\hline LGFP-1 & $49.74 \pm 1.22$ & $20.99 \pm 0.28$ & $0.96 \pm 0.01$ & $40.2 \pm 0.3$ & 0.01 & 0.01 & 0.03 & 0.01 & 1 & 0.03 & 0.02 \\
\hline LGFP-2 & $47.21 \pm 1.32$ & $16.86 \pm 0.10$ & $0.45 \pm 0.02$ & $14.0 \pm 0.3$ & 0.01 & 0.01 & 0.05 & 0.01 & 1 & 0.03 & 0.02 \\
\hline LGFP-3 & $44.73 \pm 2.43$ & $18.33 \pm 0.43$ & $0.18 \pm 0.01$ & $8.7 \pm 0.2$ & 0.01 & 0.01 & 0.05 & 0.01 & 1 & 0.03 & 0.01 \\
\hline LGFP-4 & $41.00 \pm 0.25$ & $17.01 \pm 0.44$ & $0.29 \pm 0.00$ & $2.7 \pm 0.1$ & 0.01 & 0.02 & 0.04 & 0.01 & 1 & 0.02 & 0.02 \\
\hline
\end{tabular}

Man: mannose; Rha: rhamnose; Glc A: glucuronic acid; Glc: glucose; Gal: galactose; Xyl: xylose; Fuc: fucose.

In order to further characterize the chemical structure of the GFP and LGFPs, the respective FT-IR spectra were examined (Figure 5). Based on previous reports $[17,23,24]$, the O-H stretching vibration appeared at $3300 \mathrm{~cm}^{-1}$, and C-H stretching vibration appeared at $2940 \mathrm{~cm}^{-1}$. The absorption peaks at $1620 \mathrm{~cm}^{-1}$ and $1420 \mathrm{~cm}^{-1}$ represents the asymmetric and symmetric stretching vibration of $\mathrm{C}=\mathrm{O}$, respectively. The absorption peaks at $1220 \mathrm{~cm}^{-1}$ indicates $\mathrm{S}=\mathrm{O}$ stretching vibration and that at $1020 \mathrm{~cm}^{-1}$ correspond to $\mathrm{C}-\mathrm{O}-\mathrm{H}$ deformation vibration. Feature absorption at $840 \mathrm{~cm}^{-1}$ reflects $\mathrm{C}-\mathrm{O}-\mathrm{S}$ symmetry stretching vibration. 


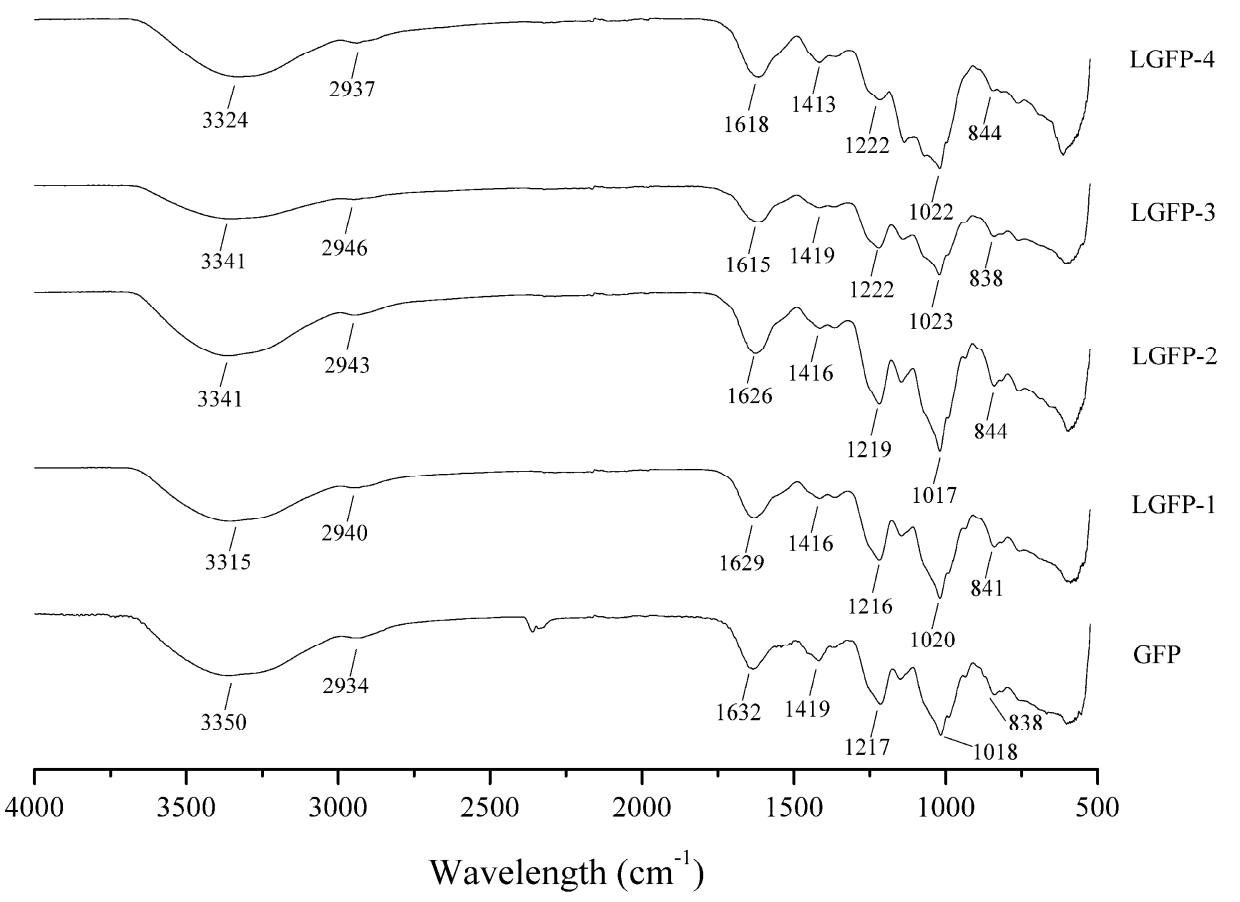

Figure 5. Fourier transform infrared (FT-IR) spectra of GFP and LGFPs in regions from 4000 to $500 \mathrm{~cm}^{-1}$.

\subsection{Cytotoxic Activity}

The specific results of MTT (3-(4,5-dimethyl-2-thiazolyl)-2,5-diphenyl-2-H-tetrazolium bromide) assay used to detect the cytotoxicity of GFP and LGFPs on DF-1 cells were shown in Table 3. It was considered that the polysaccharides do not have cytotoxic activity to DF-1 cells as the relative survival is over $85 \%[25,26]$. These results suggested that $2 \mathrm{mg} / \mathrm{mL}$ was still safe for all samples.

Table 3. Relative Survival Rate of DF-1 cells.

\begin{tabular}{cccccccc}
\hline $\begin{array}{c}\text { Concentration } \\
(\mathbf{m g} / \mathbf{m L})\end{array}$ & $\mathbf{2}$ & $\mathbf{1}$ & $\mathbf{0 . 5}$ & $\mathbf{0 . 2 5}$ & $\mathbf{0 . 1 2 5}$ & $\mathbf{0 . 0 6 2 5}$ & $\mathbf{0 . 0 3 1 2 5}$ \\
\hline GFP & $0.95 \pm 0.02$ & $1.00 \pm 0.06$ & $1.03 \pm 0.07$ & $1.08 \pm 0.01$ & $1.07 \pm 0.04$ & $1.05 \pm 0.09$ & $1.02 \pm 0.06$ \\
LGFP-1 & $0.96 \pm 0.02$ & $1.00 \pm 0.05$ & $1.05 \pm 0.04$ & $1.05 \pm 0.08$ & $1.01 \pm 0.04$ & $0.99 \pm 0.04$ & $1.00 \pm 0.04$ \\
LGFP-2 & $0.94 \pm 0.05$ & $1.06 \pm 0.04$ & $1.01 \pm 0.02$ & $1.05 \pm 0.04$ & $1.05 \pm 0.05$ & $1.01 \pm 0.04$ & $1.03 \pm 0.07$ \\
LGFP-3 & $0.95 \pm 0.02$ & $1.02 \pm 0.05$ & $1.04 \pm 0.10$ & $0.99 \pm 0.03$ & $1.03 \pm 0.03$ & $0.99 \pm 0.05$ & $1.03 \pm 0.04$ \\
LGFP-4 & $0.96 \pm 0.10$ & $0.98 \pm 0.03$ & $1.03 \pm 0.06$ & $1.01 \pm 0.05$ & $1.01 \pm 0.03$ & $1.04 \pm 0.07$ & $1.09 \pm 0.03$ \\
\hline
\end{tabular}

The safe concentration of GFP and LGFPs was tested using MTT assay. All treatments were performed in triplicate. The relative survival rate reflected the cytotoxity of GFP and LGFPs.

\subsection{Anti-ALV-J Activity In Vitro}

\subsubsection{ALV-Specific Antigen Detection}

ELISA method was applied to preliminary verify the anti-ALV-J activity of polysaccharides preliminary. $S / P$ value represented the relative expression of p27 antigen and was calculated by the following equation: $S / P=$ (Sample mean - Negative control mean) $/($ Positive control mean Negative control mean). As presented in Figure 6, under the concentration of $2 \mathrm{mg} / \mathrm{mL}$, the $S / P$ value of all of the tested groups were lower than the virus control, which means that the ALV p27 antigen of polysaccharides treated groups were dramatically lower than virus control. The effect of LGFP-2, LGFP-3, and LGFP-4 was better than that of GFP and LGFP-1, which possess higher Mw. Among them, LGFP-3 showed the best anti-ALV-J activity with a $S / P$ value of 0.13 , thus, LGFP-3 was cautiously chosen for further study. 


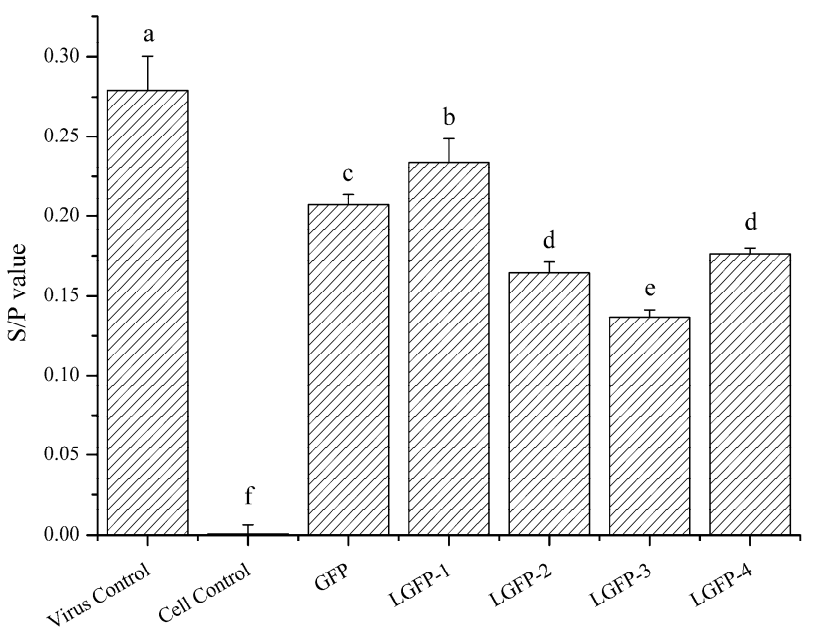

Figure 6. Expression of ALV-J p27 antigen. Antiviral activity of GFP and LGFPs were determined by ALV p27 antigen test kit. Results are recognized as positive when $S / P$ value is greater than 0.2 . Data are shown as the Mean $+\mathrm{SD}$. Values with different letters in the same column $(\mathrm{a}-\mathrm{f})$ are significantly different $(p<0.05)$ from each other.

\subsubsection{Action Phase of Polysaccharides}

Different plant polysaccharides exerted various antiviral characteristics $[1,27,28]$. In order to explore the action phase of the samples, LGFP-3 was assayed following different conditions, as indicated in Section 4.7.2. All of the treatments were applied to cells and virus in vitro, and the antiviral activity was detected by ELISA. The results showed in Figure 7 illustrated that the $S / P$ value of Ad group was 0.15, significantly lower than the virus control that was 0.24 , and also lower than that of BA and AA. This means that the GFP-3 might inhibit virus adsorption onto the DF- 1 cells. The p27 expression of BA and AA (both 0.23) groups was lower than the virus control but the difference was not significantly $(p>0.05)$, which indicated that the treatment with polysaccharides before or after virus inoculation did not significantly decrease the virus infection.

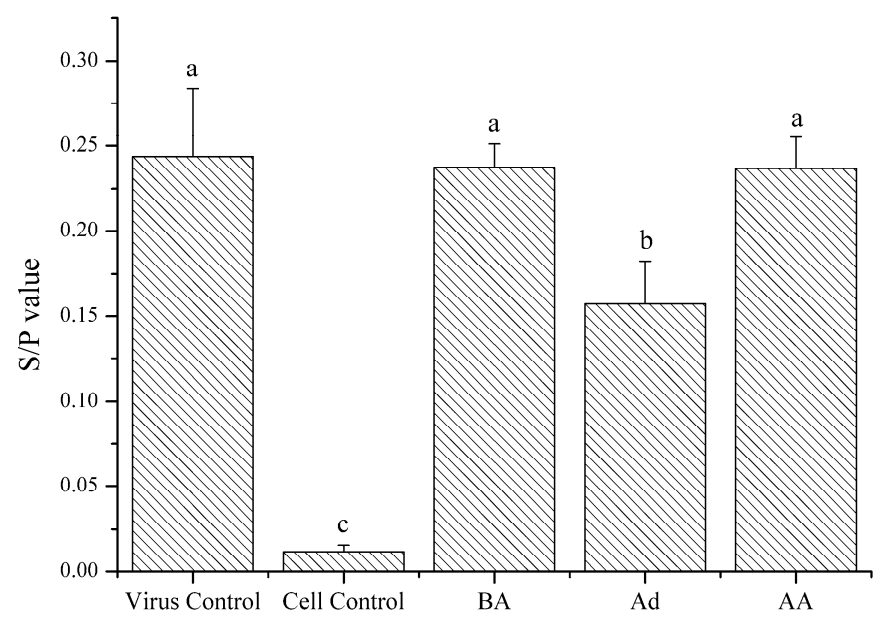

Figure 7. Expression of p27 after different modes of administration: LGFP-3 treated DF-1 cells before adsorption (BA); LGFP-3 treated virus at the adsorption phase (Ad); and, LGFP-3 treated DF-1 cells after adsorption (AA). The final concentrations of LGFP-3 were all $1 \mathrm{mg} / \mathrm{mL}$ in these three administration. DF-1 cells with and without inoculation were used as the virus and cell control, respectively. Data are shown as the Mean + SD. Values with different letters in the same column $(a-c)$ are significantly different $(p<0.05)$ from each other. 


\subsubsection{Gene Relative Expression of ALV-J}

Real time PCR was performed to evaluate the ALV-J gene expression with or without LGFP-3 treatment. The results were presented in Figure 8. The expression of ALV-J gene decreased significantly after treatment with LGFP-3 (1000 and $200 \mu \mathrm{g} / \mathrm{mL}$ ), and the suppression was dose-dependent. Treatment with $1000 \mu \mathrm{g} / \mathrm{mL}$ LGFP-3 caused the strongest inhibition against ALV-J adsorption; the relative gene expression of $200 \mu \mathrm{g} / \mathrm{mL}$ in the experiment group was 42.52 , weaker than $1000 \mu \mathrm{g} / \mathrm{mL}$ group but significantly lower than virus control. While handling with $40 \mu \mathrm{g} / \mathrm{mL}$ LGFP-3, the gene expression was higher than the other two concentrations and even higher than the virus control. This suggested that under a low concentration, the LGFP might promote ALV-J adsorption.

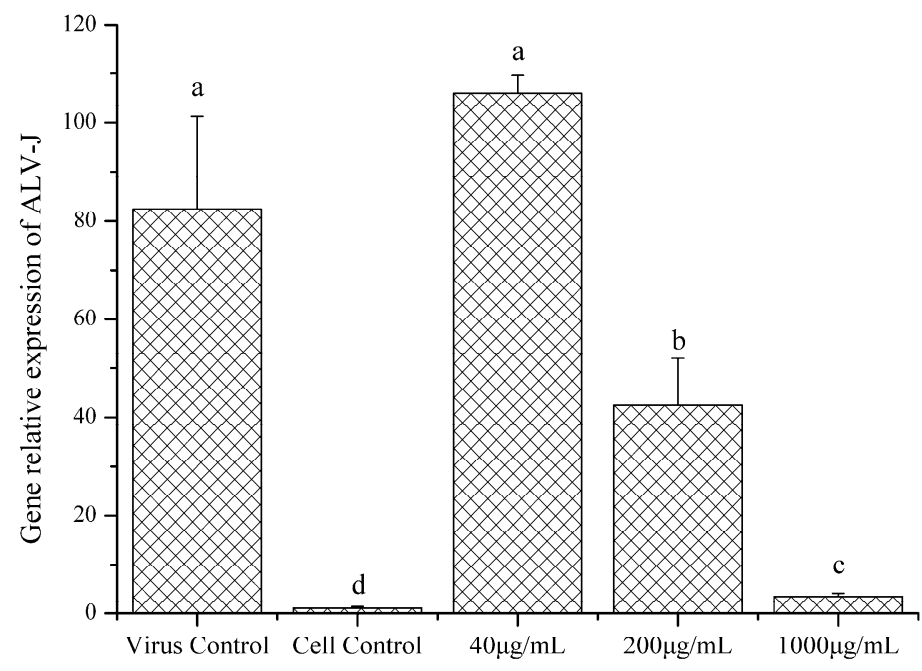

Figure 8. Gene relative expression of ALV-J measured with real-time PCR. DF-1 cells with or without inoculation were used as the virus and cell control, respectively. Data are shown as the Mean + SD. Values with different letters in the same column $(a-d)$ are significantly different $(p<0.05)$ from each other.

\subsubsection{Western-Blot and Indirect Immunofluorescence Assay (IFA) Analysis}

To further investigate the variation of ALV-J when treated with LGFP-3 as compared to cell and virus control, western-blot and IFA were also used; the results were shown in Figures 9 and 10, respectively. As it happened with the results of real time PCR, in western-blot analysis, expression of ALV-J gp85 protein was almost the same as virus control when treated with $40 \mu \mathrm{g} / \mathrm{mL}$ LGFP-3. However, when the concentration was $1000 \mu \mathrm{g} / \mathrm{mL}$, the gp 85 protein expression significantly decreased and gained a much greater effect when compared with $200 \mu \mathrm{g} / \mathrm{mL}$ and $40 \mu \mathrm{g} / \mathrm{mL}$ LGFP-3. These results also showed that the antiviral effects were dose dependent.

A more direct observation of DF-1 cells infected by ALV-J could be obtained from IFA. Results showed that five days after inoculation, the green fluorescence signal intensity of $40 \mu \mathrm{g} / \mathrm{mL}$ group was the strongest and similar to that of the virus control. The majority of the DF- 1 cells were also infected with ALV-J in the $200 \mu \mathrm{g} / \mathrm{mL}$ group but less in number than the virus control group. Cells that were treated with $1000 \mu \mathrm{g} / \mathrm{mL}$ LGFP-3 had the lowest virus expression. The antiviral effects increased following by the increase of LGFP-3 concentration, a reaction to that real time PCR and Western blot. 


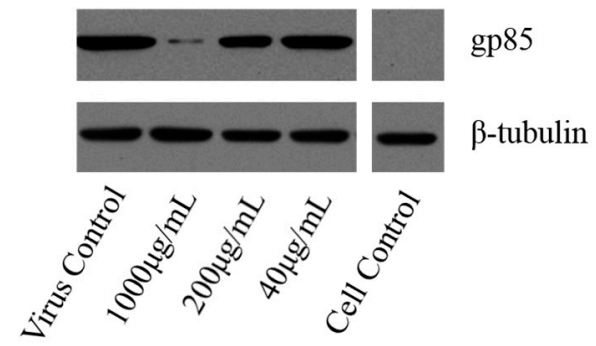

Figure 9. Expression of ALV-J gp85 protein evaluated by western-blot. DF-1 cells with or without inoculation were used as the virus and cell control, respectively.
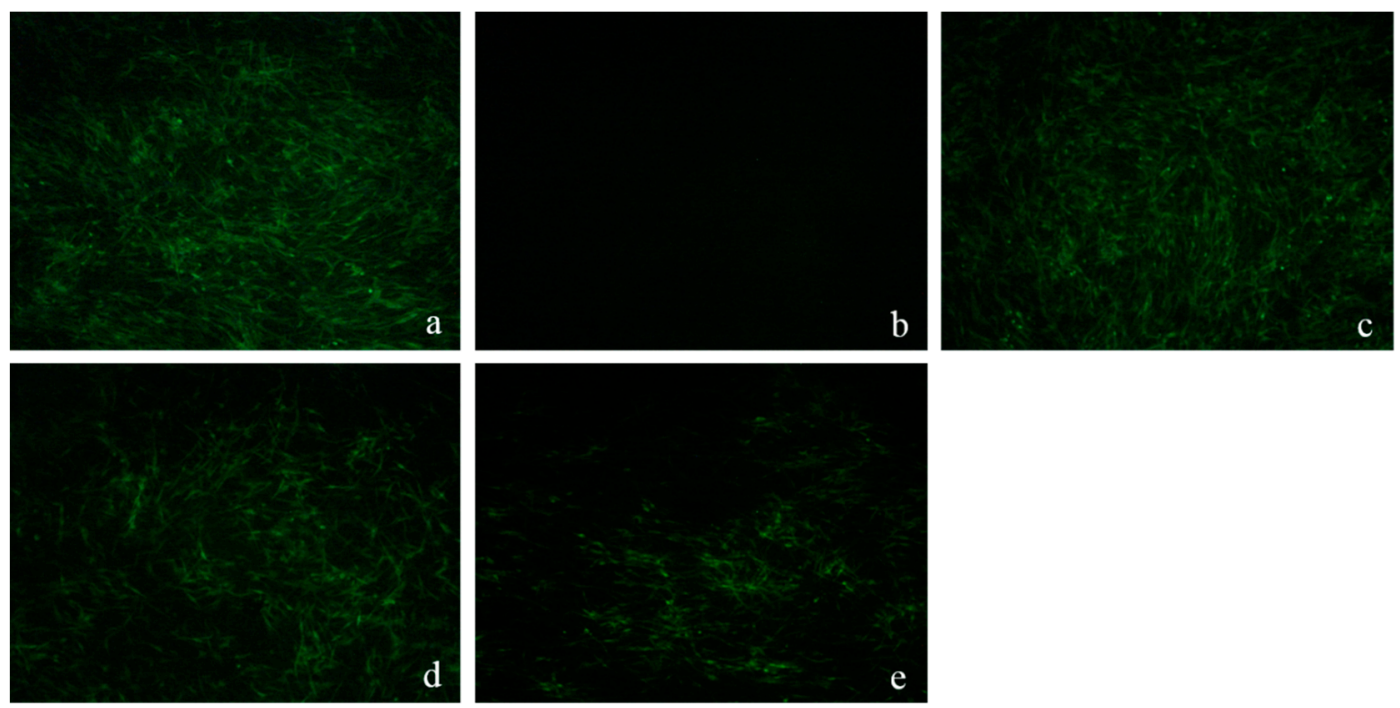

Figure 10. Expression of ALV-J gp85 protein evaluated by IFA. (a): virus control; (b): cell control; (c): ALV-J treated with $40 \mu \mathrm{g} / \mathrm{mL}$ LGFP-3; (d): ALV-J treated with $200 \mu \mathrm{g} / \mathrm{mL}$ LGFP-3; and, (e): ALV-J treated with $1000 \mu \mathrm{g} / \mathrm{mL}$ LGFP-3.

\section{Discussion}

The GFP was recognized for its various biological activities [14,29,30]. However, researches focusing on the degradation of GFP and antiviral activity of LGFP are still scarce. Therefore, it is necessary and significant to explore the influence of degradation conditions on the Mw of GFP and the antiviral activity of LGFP. For all of the degradation methods, $\mathrm{H}_{2} \mathrm{O}_{2}$ oxidative degradation was characterized for its mild reaction and low cost; besides, the unreacted excess $\mathrm{H}_{2} \mathrm{O}_{2}$ is easy to remove. Because of the advantages mentioned above, $\mathrm{H}_{2} \mathrm{O}_{2}$ oxidative degradation has been widely used in degrading polysaccharides such as chitosan, starch, and cellulose [31-33]. Further, the $\mathrm{pH}, \mathrm{H}_{2} \mathrm{O}_{2}$ concentration and temperature were considered to have a great impact on the degradation rate $[17,34]$.

In this study, the GFP degradation rate was shown to be positively related to temperature, $\mathrm{H}_{2} \mathrm{O}_{2}$ concentration, and negatively to $\mathrm{pH}$ in general. Probably, during the degradation process, $\mathrm{H}_{2} \mathrm{O}_{2}$ could generate free radicals such as $\mathrm{HOO}^{-},{ }^{\bullet} \mathrm{O}_{2}$, and $\mathrm{HO}^{\bullet}$, which could remove a $\mathrm{H}$ atom bonded to contributing to the fracture of the glycosidic linkages [35]. Our results showed that the degradation for $0.03 \%$ and $0.15 \% \mathrm{H}_{2} \mathrm{O}_{2}$ were slower than that of $0.3 \%$ in the first $90 \mathrm{~min}$. This might suggest that a higher $\mathrm{H}_{2} \mathrm{O}_{2}$ concentration meant that more free radicals are produced in solution, therefore accelerating the degradation. When considering that the degradation results for $0.6 \%$ and $1.5 \% \mathrm{H}_{2} \mathrm{O}_{2}$ were same as the $0.3 \%$ from the beginning to the end, so, concentration at $0.3 \%$ was enough for GFP degradation. However, after $90 \mathrm{~min}$, the $0.03 \%$ and $0.15 \%$ groups were gradually approached to the $0.3 \%$ group, and the final results were basically the same for the three groups. This suggests that 
a high $\mathrm{H}_{2} \mathrm{O}_{2}$ concentration might speed up the degradation rate, but it dose not influence the final results. Another parameter that affects the degradation of GFP might be $\mathrm{pH}$. For example, Iqbal et al. degraded dextran at $80{ }^{\circ} \mathrm{C}$ for $2 \mathrm{~h}$, and verified that the $\mathrm{Mw}$ of the product was $270 \mathrm{kDa}$ with $\mathrm{pH}$ of 1.8 , while the $\mathrm{Mw}$ decreased to only $77 \mathrm{kDa}$ for $\mathrm{pH} 1.4$ [36]. In our study, compared with $\mathrm{pH} 3,4$, and 8, $\mathrm{pH} 1$ and 2 could significantly accelerate the degradation probably because $\mathrm{pH}$ could also affect the generation rate of free radicals in the solution. Therefore, in an acidic environment provided by a low $\mathrm{pH}$, polysaccharides could be degraded more easily. Another important factor in GFP degradation is temperature. As shown in Figure 3, $10 \mathrm{kDa}$ products could be obtained within $60 \mathrm{~min}$ at $90{ }^{\circ} \mathrm{C}$ and $100{ }^{\circ} \mathrm{C}$, but at $60{ }^{\circ} \mathrm{C}$ and $70{ }^{\circ} \mathrm{C}$, the $\mathrm{Mw}$ of the products were $63 \mathrm{kDa}$ and $16 \mathrm{kDa}$ only after $240 \mathrm{~min}$. Hence, the $\mathrm{Mw}$ of the degradation products decreased significantly with the increase of temperature. There, we adopted $90^{\circ} \mathrm{C}$ to prepare LGFPs (Table 1 ).

Based on the degradation results, several LGFPs were prepared and the chemical composition of GFP and LGFPs were also characterized. According to the results, we found that the protein content were reduced with the decrease of $\mathrm{Mw}$ in general, which indicated that the degradation was a benefit for protein removal. Along with the decrease of $\mathrm{Mw}$, and the total sugar content also decreased, it might because of the comprehensive effect, which is caused by the temperature, $\mathrm{H}^{+}$, and free radicals in the degradation process. The monosaccharide composition results showed that all of the samples were mainly composed of galactose, the other monosaccharide content was extremely low. The pattern mentioned in FT-IR indicated that GFP and LGFPs were all sulfated polysaccharides and the degradation process did not change the chemical structure of GFP.

ALV-J has gradually spread in China and caused great losses to poultry breeding industry [37-39]. When compared with other ALVs, high recombination of ALV-J and selection pressure lead to the faster variation rate [40,41], which caused great difficulties in preventing and treating ALV-J outbreaks.

Polysaccharides from the algae were found to exert inhibition to many viruses [42-44]. To verify the suppression of GFP and LGFPs to ALV-J, the ALV p27 antigen was detected in the presence or absence of the polysaccharides. P27 antigen is a common protein in ALVs, but it is often used to determine the ALV-J infection levels in the laboratory when the pathogen is ensured. Results in the study showed that all of the samples could significantly inhibit the expression of p27 antigen, and LGFP-2, 3, and 4 were better than GFP and LGFP-1. Among them, LGFP-3 with a Mw of $8.7 \mathrm{kDa}$ exerted the best inhibition effect.

In order to determine the function time-point of polysaccharides on ALV-J, LGFP-3 was chosen for further experiments. Figure 5 demonstrated that p27 antigen levels reduced only when the virus and LGFP-3 were administered simultaneously. Further, the BA and AA treatments were similar to the virus control. Therefore, the polysaccharides might mainly inhibit ALV-J adsorption on host cells. This was also observed in some other reports. Bouhlal et al., for example, found that polysaccharides extracted from Sphaerococcus coronopifolius and Boergeseniella thuyoides inhibited HSV-1 adsorption onto host cells [28], and Bourgougnon et al. suggested that the polysaccharides from Schizymenia dubyi could suppress HIV and the activity was mainly attributed to the inhibition of virus to cell attachment [45]. While Wang et al. found that fucoidan from Kjellmaniella crassifolia could inhibit the influenza A virus (IAV) treated with fucoidan before or after inoculation [27]. It seems that the action phase of fucoidan was not the same as LGFP. This is probably because the monosaccharide composition and the chemical structure of fucoidan, and also the viruses were different from this study. In addition, many researches showed that the sulfate content played a very important role in polysaccharides activities [46-49]. However, in this research, although the inhibition effect of LGFP-3 was the best, the sulfate content of LGFP-3 was not the highest. Perhaps, the inhibition effect of GFP and LGFPs to ALV-J was not only related to the sulfate content but also to the Mw of the polysaccharides or the sulfate pattern of distribution. According to the results, we may deduce that LGFP with a Mw of about $8.7 \mathrm{kDa}$ might bind to some specific receptors on the cells with a more suitable structure and ionic interactions between polysaccharides and cells, or it could fully bind to ALV-J particles and block the specific recognition between virus and cells, thereby preventing the virus from adsorption. In order to 
further prove the LGFP-3 anti-ALV-J effect, virus genes, and specific protein expression were tested by real-time PCR, Western-blot and IFA. A significant suppression of ALV-J gene and gp85 protein expression were detected. Based on the real-time PCR results, gene expression of virus control were 24-times higher than that of $1000 \mu \mathrm{g} / \mathrm{mL}$ LGFP-3 group, thus the virus replication was significantly decreased. From the western-blot and IFA results, it can be observed that the virus protein expression and the number of ALV-J decreased significantly in the groups under 1000 and $200 \mu \mathrm{g} / \mathrm{mL}$ treatment. Thus the quantity of viral protein synthesis was also reduced. All of the above results showed that LGFP-3 could inhibit the ALV-J adsorption and reduce the infection probability of virus. Similar results were obtained by Yu et al., who discovered that the polysaccahrides from Taishan Pinus massoniana pollen could directly coat to the virus envelope protein, which would bind to the cell surface receptor, thereby affecting the virus adsorption [1]. Because LGFP-3 had no impact on ALV-J when applied before adsorption (BA), we speculated that our samples could not bind to the cell membrane, and the possible way was to interact with the virus envelope protein just like the polysaccahrides from Taishan Pinus massoniana pollen. But, considering the complex configuration of our samples, the action targets might be more and the specific mechanism needs to be elucidated in the future.

\section{Materials and Methods}

\subsection{Seaweeds Samples and Reagents}

G. filicina was collected from the number two bathing beach of Qingdao, China in January 2016. The seaweeds were washed with distilled water to remove salt, sediment, and other impurities, then dried at $50{ }^{\circ} \mathrm{C}$ in an oven to constant weight and stored at room temperature. All of the reagents used were of analytical grade.

\subsection{Extraction of GFP}

Traditional hot water extraction and alcohol precipitation method [26] was used with some modifications. Briefly, the dried algae were mixed with 60 -fold volume of distilled water and maintained at $100{ }^{\circ} \mathrm{C}$ for $4 \mathrm{~h}$. After cooling down, the polysaccharide solution was filtered and condensed to $1 / 2$ volume by a rotavapor. Then, the supernatant was dialyzed at tap water for $24 \mathrm{~h}$ and then changed to distilled water for $24 \mathrm{~h}$, respectively, using dialysis tube with a $3.5 \mathrm{kDa} \mathrm{Mw}$ cut off. The liquid was concentrated to $1 / 4$ volume and after that 3 -fold volume anhydrous ethanol was added to precipitate polysaccharides. The mixture was placed over-night at $4{ }^{\circ} \mathrm{C}$ and then centrifuged. The precipitate was freeze-dried and the yield (\%) of the polysaccharide was calculated.

\subsection{Influence of $\mathrm{H}_{2} \mathrm{O}_{2}$ Oxidation on GFP Degradation and Preparation of LGFP}

A $0.8 \mathrm{~g}$ mass of GFP was dissolved in $40 \mathrm{~mL}$ distilled water, added with $\mathrm{H}_{2} \mathrm{O}_{2}$ solution, and adjusted $\mathrm{pH}$ by hydrochloric acid or sodium hydroxide, and then heated in a water bath with stirring. Every $30 \mathrm{~min}, 0.5 \mathrm{~mL}$ samples were removed from the reaction solution. After being filtrated with a $0.22 \mu \mathrm{m}$ polyethersulfone filter (Tianjin Jinteng Experiment Equipment Co., Ltd, Tianjin, China), the $\mathrm{Mw}$ of the samples was determined by high performance gel permeation chromatography (HPGPC) to investigate the effect of $\mathrm{pH}\left(1,2,3,4\right.$, and 8), final concentration of $\mathrm{H}_{2} \mathrm{O}_{2}(0.03 \%, 0.15 \%, 0.3 \%$, $0.6 \%$, and $1.5 \%)$ in reaction solution and temperature $\left(60{ }^{\circ} \mathrm{C}, 70{ }^{\circ} \mathrm{C}, 80{ }^{\circ} \mathrm{C}, 90{ }^{\circ} \mathrm{C}\right.$, and $\left.100{ }^{\circ} \mathrm{C}\right)$ on the GFP degradation. Afterwards, according to the above results, LGFPs were prepared under different conditions.

\subsection{Chemical Characterization}

The Mw of GFP and LGFPs was measured by HPGPC method with a TSK gel G3000PWxl column, and using $0.1 \mathrm{~mol} / \mathrm{L} \mathrm{Na}_{2} \mathrm{SO}_{4}$ as the mobile phase on Agilent 1260 HPLC systerm equipped with a refractive index detector. The column temperature was $35{ }^{\circ} \mathrm{C}$ and flow rate was $0.5 \mathrm{~mL} / \mathrm{min}$. Dextran 
standards (Mw 1000, 5000, 12,000, 50,000, 80,000, 270,000, and 670,000, Sigma, Mendota Heights, MN, USA) were used to calibrate the column.

Total sugars were analyzed by phenol-sulphuric acid method [50] using galactose as the standard. Bradford's method [51] was used to detect the protein content and using bovine serum albumin (BSA) as the standard. Sulfated content was determined by barium chloride gelatin method [52]. The Fourier transform infrared (FT-IR) spectra of the samples were recorded by Nicolet-360 FT-IR spectrometer (Thermo Fisher, Waltham, MA, USA) in KBr disks using a scan range from 500 to $4000 \mathrm{~cm}^{-1}$.

The monosaccharide composition (molar ratio) was analyzed using 1-phenyl-3-methyl-5pyrazolone (PMP) pre-column derivation HPLC [53]. Briefly, $10 \mathrm{mg}$ samples were put into the ampoule and $1 \mathrm{~mL}$ distilled water was added then the mixture was hydrolyzed in $4 \mathrm{~mol} / \mathrm{L}$ trifluoroacetic acid for $4 \mathrm{~h}$ at $110{ }^{\circ} \mathrm{C}$ in an oven followed by neutralization with sodium hydroxide to $\mathrm{pH} 5-6$. Later, the pre-column derivatives were carried out with PMP and separated by HPLC using a YMC Pack ODS AQ column. The mannose, rhamnose, fucose, galactose, xylose, glucose, and glucuronic acid standards were obtained from Sigma Aldrich (St. Louis, MO, USA).

\subsection{Cell Lines, Cell Culture, Virus and Antibodies}

A DF-1 cell line, a NX0101 strain of ALV-J, and the ALV-J gp85-specific monoclonal antibody were kindly gifted by Prof. Cheng, Shandong Agricultural University. The DF-1 cells were cultured in Dulbecco's modified Eagle's medium (DMEM) provided with 100 units $/ \mathrm{mL}$ of penicillin and $100 \mu \mathrm{g} / \mathrm{mL}$ of streptomycin, and supplemented with $10 \%(v / v)$ or $1 \%(v / v)$ fetal bovine serum (FBS) as the growth medium (GM) or maintenance medium (MM), respectively. The ALV-J titer was tested using DF-1 monolayers and expressed by tissue culture infectious dose 50 (TCID 50 ) using the Reed-Muench formula. $100 \mathrm{TCID}_{50}$ of ALV-J was used in subsequent experiments.

\subsection{Determination of Cytotoxic Activity}

MTT assay was used to evaluate the cytotoxic activity of GFP and LGFP on DF-1 cells. DF-1 cell monolayers grown in 96-well plate were supplied with the $100 \mu \mathrm{L} \mathrm{MM}$ as the cell control or $100 \mu \mathrm{L}$ polysaccharides solution that were dissolved in MM (the maximum concentration was $2 \mathrm{mg} / \mathrm{mL}$ and diluted in 2-fold steps to $0.03125 \mathrm{mg} / \mathrm{mL}$ ). All of the treatments were performed in triplicate. After $24 \mathrm{~h}$, the liquid was removed; $20 \mu \mathrm{L}$ MTT was added and the cells were incubated for another $4 \mathrm{~h}$. Then, the MTT was discarded and $100 \mu \mathrm{L}$ DMSO was added. Finally, the enzyme-linked immunosorbent assay reader (iMark ${ }^{\mathrm{TM}}$ BIO-RAD, Hercules, CA, USA) was used to determine the absorbance of each well at $490 \mathrm{~nm}$. The cytotoxic activity was represented by the relative survival rate of DF-1 cells and calculated by the formula: survival rate $(\%)=(A s / A c) \times 100 \%$, where $A c$ and $A$ s were the absorbance of cell control $(A c)$ and experimental group $(A s)$, respectively. When the survival rates were higher than $85 \%$, it was considered that the samples had no cytotoxicity on DF-1 cells.

\subsection{Anti-ALV-J Activity In Vitro}

\subsubsection{ALV Specific Antigen Detection}

DF-1 cell monolayers grown in 96-well plate were infected with 100 TCID 50 of ALV-J, meanwhile, different polysaccharides solutions at a final concentration of $2 \mathrm{mg} / \mathrm{mL}$, which were dissolved in $\mathrm{MM}$ were added. After $2 \mathrm{~h}$ incubation at $37^{\circ} \mathrm{C}$, the cells were washed and covered with MM containing corresponding polysaccharides at a concentration of $2 \mathrm{mg} / \mathrm{mL}$, subsequently, the cell control (without infection of ALV-J) and virus control (without exposure to polysaccharides) were also set. After $24 \mathrm{~h}$ of incubation, the viral titers were measured using the ALV p27 antigen test kit (Beijing IDEXX-Yuanheng Laboratories, Co. Ltd., Beijing, China) following by the instructions of the manufacturer. The relative expressions of p27 antigen were calculated by the following equation: $S / P=$ (Sample mean - Negative control mean)/(Positive control mean - Negative control mean). 


\subsubsection{Detection of the Polysaccharides Action Phase}

DF-1 cells grown in 96-well plate were infected with 100 TCID $_{50}$ of ALV-J. Then, they were treated with MM containing polysaccharides at a final concentration of $1 \mathrm{mg} / \mathrm{mL}$ in different ways. According to the artificially divided viral infection phase, the specific operations were as follows:

Before Adsorption (BA): The DF-1 cells were covered with MM containing polysaccharides for $2 \mathrm{~h}$ before the inoculation. After that, the cells were washed and then incubation with ALV-J for $2 \mathrm{~h}$. After inoculation, the cells were washed again and maintained with MM for $24 \mathrm{~h}$.

Adsorption (Ad): The cells were treated with MM containing polysaccharides at the time they were infected with ALV-J. After incubation at $4{ }^{\circ} \mathrm{C}$ for $2 \mathrm{~h}$, the supernatant was removed and replaced by simple MM.

After Adsorption (AA): The DF-1 cells were infected with ALV-J and incubated for $2 \mathrm{~h}$, and then the cells were washed and recovered with polysaccharides dissolved in MM.

The cell control and virus control were also served. After $24 \mathrm{~h}$ incubation, all of the supernatants were collected and the viral titers were measured by ALV p27 antigen test kit.

\subsubsection{Viral Gene Relative Expression and Protein Expression}

DF-1 cells grown in 12-well plate to monolayers in simple MM medium were infected with $100 \mathrm{TCID}_{50}$ of ALV-J and treated with MM containing polysaccharides at a final concentration of $1000 \mu \mathrm{g} / \mathrm{mL}, 200 \mu \mathrm{g} / \mathrm{mL}$, and $40 \mu \mathrm{g} / \mathrm{mL}$. After $2 \mathrm{~h}$ adsorption at $37^{\circ} \mathrm{C}$, the supernatant was discarded and replaced by simple MM, then the cells were incubated at $37^{\circ} \mathrm{C}$ with $5 \% \mathrm{CO}_{2}$ for about $24 \mathrm{~h}$.

Real-time PCR: The ALV-J gene replication levels in DF-1 cells were determined by real-time PCR. In brief, RNAprep Pure Cell/Bacteria Kit (TIANGEN BIOTECH Co. Ltd., Beijing, China) was used to extract the total RNA from the treated DF-1 cells following the manufacturer's instructions. Then, PrimeScript ${ }^{\mathrm{TM}}$ RT reagent Kit with gDNA Eraser (Takara BIO INC, Dalian, China) was applied for reverse transcription immediately. The cDNA produced by reverse transcription was used for real-time PCR as performed by SYBR ${ }^{\circledR}$ Premix ExTaq ${ }^{\mathrm{TM}}$ Kit (Takara BIO INC, Dalian, China). The forward primer (5'-GCGTGCGTGGTTATTATTTC-3') and reverse primer (5'-AATGGTGAGGTCGCTGACTGT-3') were used as the ALV-J primers, the forward primer for internal control GAPDH was (5'-GAACATCATCCCAAGCGTCCA-3 ${ }^{\prime}$ ) and reverse primer (5'-CGGCAGGTCAGGTCAACAAC-3'). The amplification cycles were carried out as follows: $95^{\circ} \mathrm{C}$ for $30 \mathrm{~s} ; 95^{\circ} \mathrm{C}$ for $5 \mathrm{~s}$ and $60{ }^{\circ} \mathrm{C} 34 \mathrm{~s}\left(34\right.$ cycles); $95^{\circ} \mathrm{C}$ for $15 \mathrm{~s}$ and $60^{\circ} \mathrm{C}$ for $60 \mathrm{~s}$. The results were calculated by the formula $2^{-\Delta \Delta C t}[54,55]$.

The expression of ALV-J gp85 protein was detected by western blot and IFA.

Western-blot: After $24 \mathrm{~h}$ incubation, the cells were lysed and separated by SDS-PAGE $(12 \%$ acrylamide gels). Proteins were blocked with Tris-buffered saline (TBS) buffer containing $5 \%(w / v)$ dry skimmed milk, and $0.1 \%(v / v)$ Tween 20 for $1 \mathrm{~h}$ at room temperature. Membranes were then incubated overnight at $4{ }^{\circ} \mathrm{C}$ with mouse ALV-J gp85-specific monoclonal antibody or $\beta$-tubulin antibody as control. The membranes were washed with TBS-Tween and then incubated with HRP-linked secondary antibody $(1: 10,000)$ for $1 \mathrm{~h}$ at room temperature. Membranes were washed and protein densities were detected using chemiluminesence detection reagents.

IFA: After inoculation, the DF- 1 cells were incubated at $37^{\circ} \mathrm{C}$ with $5 \% \mathrm{CO}_{2}$ for five days and then IFA was executed as follows. The cells were fixed with cold acetone and ethanol ( $3: 2$ for $v / v)$ for about 10 min washed with PBS and the gp85-specific monoclonal antibody was added. The mixture was incubated overnight at $4{ }^{\circ} \mathrm{C}$ and washed thoroughly with PBS to eliminate the uncombined antibodies. Afterwards, the cells were treated with goat anti-mouse IgG-FITC at $37^{\circ} \mathrm{C}$ for $1 \mathrm{~h}$, washed with PBS for five times and then photographed on an inverted fluorescence microscope. 


\subsection{Statistical Analysis}

Statistical analysis was performed using SPSS and the difference among groups was analyzed by one-way ANOVA.

\section{Conclusions}

In this study, the polysaccharides ( $\mathrm{Mw} 216 \mathrm{kDa}$ ) extracted from G. filicina were degraded by $\mathrm{H}_{2} \mathrm{O}_{2}$ oxidative method. The degradation rate was positively related to temperature, $\mathrm{H}_{2} \mathrm{O}_{2}$ concentration, and negatively to high $\mathrm{pH}$. Several LGFPs ( $\mathrm{Mw} 40,14,8.7$, and $2.7 \mathrm{kDa}$ ) were prepared under different conditions and their anti-ALV-J activity were also investigated. The results showed that initial GFP and LGFPs all possessed antiviral activity, and low $\mathrm{Mw}$ is better for the inhibition of ALV-J, LGFP-3 $(\mathrm{Mw} 8.7 \mathrm{kDa}$ ) had the best effect. The action phase of our samples was also determined. The results showed that LGFP-3 were mainly take effect when treated by Ad administration the time that ALV-J adsorbing on host cells. Further experiments indicated that after being treated with LGFP-3, the ALV-J gene and protein expression decreased significantly: it revealed that LGFP-3 inhibited virus adsorption onto DF-1 cells and contributed to the decrease of ALV-J expression. The results demonstrated that polysaccharides from G. filicina have great potential in developing as an anti-ALV-J drug. However, the antiviral activity of LGFPs in vivo and complicated mechanism in detail require further study.

Acknowledgments: This work was supported by the Commonweal Item of the State Oceanic Administration of the People's Republic of China (201505033), NSFC-Shandong joint Fund (U1606403), Shandong Province Key Research and Development Project (2016YYSP010) and Qingdao People's Livelihood Science and Technology Projects (16-6-2-41-nsh).

Author Contributions: Conceived and designed the experiment: Yuhao Sun, Xiaolin Chen, Pengcheng Li. Performed the experiments: Yuhao Sun. Analyzed the data: Yuhao Sun, Xiaolin Chen. Contributed reagents/materials/analysis tools: Xiaolin Chen, Ziqiang Cheng, Song Liu, Huahua Yu, Xueqin Wang, Pengcheng Li. Wrote the paper: Yuhao Sun, Xiaolin Chen, Pengcheng Li.

Conflicts of Interest: The author declares on conflict of interest.

\section{References}

1. Yu, C.L.; Wei, K.; Liu, L.P.; Yang, S.F.; Hu, L.P.; Zhao, P.; Meng, X.Y.; Shao, M.X.; Wang, C.W.; Zhu, L.J.; et al. Taishan Pinus massoniana pollen polysaccharide inhibits subgroup J avian leucosis virus infection by directly blocking virus infection and improving immunity. Sci. Rep. 2017, 7, 44353. [CrossRef] [PubMed]

2. Cheng, J.; Wen, S.; Wang, S.; Hao, P.; Cheng, Z.; Liu, Y.; Zhao, P.; Liu, J. gp85 protein vaccine adjuvanted with silica nanoparticles against ALV-J in chickens. Vaccine 2017, 35, 293-298. [CrossRef] [PubMed]

3. Silva, R.F.; Fadly, A.M.; Hunt, H.D. Hypervariability in the envelope genes of subgroup J avian leukosis viruses obtained from different farms in the United States. Virology 2000, 272, 106-111. [CrossRef] [PubMed]

4. Dou, W.W.; Li, H.M.; Cheng, Z.Q.; Zhao, P.; Liu, J.Z.; Cui, Z.Z.; Liu, H.G.; Jing, W.F.; Guo, H.J. Maternal antibody induced by recombinant gp85 protein vaccine adjuvanted with CPG-ODN protects against ALV-J early infection in chickens. Vaccine 2013, 31, 6144-6149. [CrossRef] [PubMed]

5. Liu, C.; Dong, J.; Waterhouse, G.I. N.; Cheng, Z.; Ai, S. Electrochemical immunosensor with nanocellulose-Au composite assisted multiple signal amplification for detection of avian leukosis virus subgroup J. Biosens. Bioelectron. 2018, 101 (Suppl. C), 110-115. [CrossRef] [PubMed]

6. Wang, Z.F.; Cui, Z.Z. Evolution of gp85 gene of subgroup J avian leukosis virus under the selective pressure of antibodies. Sci. China Ser. C-Life Sci. 2006, 49, 227-234. [CrossRef]

7. De Clerck, O.; Gavio, B.; Fredericq, S.; Barbara, I.; Coppejans, E. Systematics of Grateloupia filicina (Halymeniaceae, Rhodophyta), based on rbcL sequence analyses and morphological evidence, including the reinstatement of G. minima and the description of G. capensis sp. nov. J. Phycol. 2005, 41, 391-410.

8. Denis, C.; Morancais, M.; Gaudin, P.; Fleurence, J. Effect of enzymatic digestion on thallus degradation and extraction of hydrosoluble compounds from Grateloupia turuturu. Bot. Mar. 2009, 52, 262-267. [CrossRef]

9. Nikapitiya, C.; De Zoysa, M.; Jeon, Y.J.; Lee, J. Isolation of sulfated anticoagulant compound from fermented red seaweed Grateloupia filicina. J. World Aquac. Soc. 2007, 38, 407-417. [CrossRef] 
10. Yu, Q.; Yan, J.; Wang, S.; Ji, L.; Ding, K.; Vella, C.; Wang, Z.; Hu, Z. Antiangiogenic effects of GFP08, an agaran-type polysaccharide isolated from Grateloupia filicina. Glycobiology 2012, 22, 1343-1352. [CrossRef] [PubMed]

11. Ye, D.Y.; Jiang, Z.B.; Zheng, F.C.; Wang, H.M.; Zhang, Y.M.; Gao, F.F.; Chen, P.H.; Chen, Y.C.; Shi, G.G. Optimized extraction of polysaccharides from Grateloupia livida (Harv.) Yamada and biological activities. Molecules 2015, 20, 16817-16832. [CrossRef] [PubMed]

12. Jiang, Z.B.; Chen, Y.C.; Yao, F.; Chen, W.Z.; Zhong, S.P.; Zheng, F.C.; Shi, G.G. Antioxidant, antibacterial and antischistosomal activities of extracts from Grateloupia livida (Harv). Yamada. PLoS ONE 2013, 8, e80413. [CrossRef] [PubMed]

13. Chattopadhyay, K.; Mateu, C.G.; Mandal, P.; Pujol, C.A.; Damonte, E.B.; Ray, B. Galactan sulfate of Grateloupia indica: Isolation, structural features and antiviral activity. Phytochemistry 2007, 68, 1428-1435. [CrossRef] [PubMed]

14. Wang, S.C.; Bligh, S.W.; Shi, S.S.; Wang, Z.T.; Hu, Z.B.; Crowder, J.; Branford-White, C.; Vella, C. Structural features and anti-HIV-1 activity of novel polysaccharides from red algae Grateloupia longifolia and Grateloupia filicina. Int. J. Biol. Macromol. 2007, 41, 369-375. [CrossRef] [PubMed]

15. Ramnani, P.; Chitarrari, R.; Tuohy, K.; Grant, J.; Hotchkiss, S.; Philp, K.; Campbell, R.; Gill, C.; Rowland, I. In vitro fermentation and prebiotic potential of novel low molecular weight polysaccharides derived from agar and alginate seaweeds. Anaerobe 2012, 18, 1-6. [CrossRef] [PubMed]

16. Sun, L.Q.; Wang, L.; Zhou, Y. Immunomodulation and antitumor activities of different-molecular-weight polysaccharides from Porphyridium cruentum. Carbohydr. Polym. 2012, 87, 1206-1210. [CrossRef]

17. Li, B.; Liu, S.; Xing, R.; Li, K.; Li, R.; Qin, Y.; Wang, X.; Wei, Z.; Li, P. Degradation of sulfated polysaccharides from Enteromorpha prolifera and their antioxidant activities. Carbohydr. Polym. 2013, 92, 1991-1996. [CrossRef] [PubMed]

18. Zhao, X.; Guo, F.; Hu, J.; Zhang, L.; Xue, C.; Zhang, Z.; Li, B. Antithrombotic activity of oral administered low molecular weight fucoidan from Laminaria Japonica. Thromb. Res. 2016, 144, 46-52. [CrossRef] [PubMed]

19. Tang, F.X.; Chen, F.; Li, F. Preparation and potential in vivo anti-influenza virus activity of low molecular-weight kappa-carrageenans and their derivatives. J. Appl. Polym. Sci. 2013, 127, 2110-2115. [CrossRef]

20. Yamada, T.; Ogamo, A.; Saito, T.; Uchiyama, H.; Nakagawa, Y. Preparation of O-acylated low-molecular-weight carrageenans with potent anti-HIV activity and low anticoagulant effect. Carbohydr. Polym. 2000, 41, 115-120. [CrossRef]

21. Lee, J.B.; Takeshita, A.; Hayashi, K.; Hayashi, T. Structures and antiviral activities of polysaccharides from Sargassum trichophyllum. Carbohydr. Polym. 2011, 86, 995-999. [CrossRef]

22. Kim, W.J.; Choi, J.W.; Jang, W.J.; Kang, Y.S.; Lee, C.W.; Synytsya, A.; Park, Y.I. Low-molecular weight mannogalactofucans prevent herpes simplex virus type 1 infection via activation of Toll-like receptor 2. Int. J. Biol. Macromol. 2017, 103, 286-293. [CrossRef] [PubMed]

23. Wang, L.; Liu, H.M.; Qin, G.Y. Structure characterization and antioxidant activity of polysaccharides from Chinese quince seed meal. Food Chem. 2017, 234, 314-322. [CrossRef] [PubMed]

24. Kolsi, R.B.; Ben Salah, H.; Jardak, N.; Chaaben, R.; Jribi, I.; El Feki, A.; Rebai, T.; Jamoussi, K.; Allouche, N.; Blecker, C.; et al. Sulphated polysaccharide isolated from Sargassum vulgare: Characterization and hypolipidemic effects. Carbohydr. Polym. 2017, 170, 148-159. [CrossRef] [PubMed]

25. Seo, Y.; Lee, B.-J.; Kim, Y.A.; Lee, H.-J.; Joo, Y.H. Effects of several salt marsh plants on mouse spleen and thymus cell proliferation using MTT assay. Ocean Sci. J. 2005, 40, 209-212. [CrossRef]

26. Song, L.; Chen, X.L.; Liu, X.D.; Zhang, F.B.; Hu, L.F.; Yue, Y.; Li, K.C.; Li, P.C. Characterization and comparison of the structural features, immune-modulatory and anti-avian influenza virus activities conferred by three algal sulfated polysaccharides. Mar. Drugs 2016, 14, 4. [CrossRef] [PubMed]

27. Wang, W.; Wu, J.D.; Zhang, X.S.; Hao, C.; Zhao, X.L.; Jiao, G.L.; Shan, X.D.; Tai, W.J.; Yu, G.L. Inhibition of influenza a virus infection by fucoidan targeting viral neuraminidase and cellular EGFR pathway. Sci. Rep. 2017, 7, 10760. [CrossRef] [PubMed]

28. Bouhlal, R.; Haslin, C.; Chermann, J.-C.; Colliec-Jouault, S.; Sinquin, C.; Simon, G.; Cerantola, S.; Riadi, H.; Bourgougnon, N. Antiviral activities of sulfated polysaccharides isolated from Sphaerococcus coronopifolius (Rhodophytha, Gigartinales) and Boergeseniella thuyoides (Rhodophyta, Ceramiales). Mar. Drugs 2011, 9, 1187-1209. [CrossRef] [PubMed] 
29. Chen, X.; Yang, S.; Wang, J.; Song, L.; Xing, R.; Liu, S.; Yu, H.; Li, P. Sulfated polysaccharides isolated from cloned Grateloupia filicina and their anticoagulant activity. BioMed Res. Int. 2015, 2015, 612352. [PubMed]

30. Athukorala, Y.; Jung, W.-K.; Park, P.-J.; Lee, Y.-J.; Kim, S.-K.; Vasanthan, T.; No, H.-K.; Jeon, Y.-J. Evaluation of biomolecular interactions of sulfated polysaccharide isolated from Grateloupia filicina on blood coagulation factors. J. Microbiol. Biotechnol. 2008, 18, 503-511. [PubMed]

31. Qin, C.Q.; Du, Y.M.; Xiao, L. Effect of hydrogen peroxide treatment on the molecular weight and structure of chitosan. Polym. Degrad. Stabil. 2002, 76, 211-218. [CrossRef]

32. Parovuori, P.; Hamunen, A.; Forssell, P.; Autio, K.; Poutanen, K. Oxidation of potato starch by hydrogen-peroxide. Starch-Starke 1995, 47, 19-23. [CrossRef]

33. Zeronian, S.H.; Inglesby, M.K. Bleaching of cellulose by hydrogen peroxide. Cellulose 1995, 2, $265-272$. [CrossRef]

34. Hien, N.Q.; Phu, D.V.; Duy, N.N.; Nguyen, T.K.L. Degradation of chitosan in solution by gamma irradiation in the presence of hydrogen peroxide. Carbohydr. Polym. 2012, 87, 935-938. [CrossRef]

35. Hou, Y.; Wang, J.; Jin, W.H.; Zhang, H.; Zhang, Q.B. Degradation of Laminaria japonica fucoidan by hydrogen peroxide and antioxidant activities of the degradation products of different molecular weights. Carbohydr. Polym. 2012, 87, 153-159. [CrossRef]

36. Iqbal, S.; Marchetti, R.; Aman, A.; Silipo, A.; Ul Qader, S.A.; Molinaro, A. Enzymatic and acidic degradation of high molecular weight dextran into low molecular weight and its characterizations using novel Diffusion-ordered NMR spectroscopy. Int. J. Biol. Macromol. 2017, 103, 744-750. [CrossRef] [PubMed]

37. Xu, B.R.; Dong, W.X.; Yu, C.M.; He, Z.Q.; Lv, Y.L.; Sun, Y.H.; Feng, X.Y.; Li, N.; Lee, L.F.; Li, M. Occurrence of avian leukosis virus subgroup J in commercial layer flocks in China. Avian Pathol. 2004, 33, 13-17. [CrossRef] [PubMed]

38. Cheng, Z.Q.; Zhang, L.; Liu, S.D.; Zhang, L.J.; Cui, Z.Z. Emerging of fibro subgroup J in a flock of Chinese local breed. Acta Microbiol. Sin. 2005, 45, 584-587.

39. Sun, S.H.; Cui, Z.Z. Epidemiological and pathological studies of subgroup J avian leukosis virus infections in Chinese local "yellow" chickens. Avian Pathol. 2007, 36, 221-226. [CrossRef] [PubMed]

40. Venugopal, K.; Smith, L.M.; Howes, K.; Payne, L.N. Antigenic variants of J subgroup avian leukosis virus: sequence analysis reveals multiple changes in the env gene. J. Gen. Virol. 1998, 79, 757-766. [CrossRef] [PubMed]

41. Zavala, G.; Cheng, S.; Jackwood, M.W. Molecular epidemiology of avian leukosis virus subgroup j and evolutionary history of its $3^{\prime}$ untranslated region. Avian Dis. Dig. 2007, 51, 942-953. [CrossRef]

42. Cao, Y.G.; Hao, Y.; Li, Z.H.; Liu, S.T.; Wang, L.X. Antiviral activity of polysaccharide extract from Laminaria japonica against respiratory syncytial virus. Biomed. Pharmacother. 2016, 84, 1705-1710. [CrossRef] [PubMed]

43. Trejo-Avila, L.M.; Elizondo-Gonzalez, R.; Rodriguez-Santillan, P.; Aguilar-Briseno, J.A.; Ricque-Marie, D.; Rodriguez-Padilla, C.; Cruz-Suarez, L.E. Innocuity and anti-Newcastle-virus-activity of Cladosiphon okamuranus fucoidan in chicken embryos. Poult. Sci. 2016, 95, 2795-2802. [CrossRef] [PubMed]

44. Gheda, S.F.; El-Adawi, H.I.; El-Deeb, N.M. Antiviral profile of brown and red seaweed polysaccharides against hepatitis C virus. Iran. J. Pharm. Res. 2016, 15, 483-491. [PubMed]

45. Bourgougnon, N.; Lahaye, M.; Quemener, B.; Chermann, J.C.; Rimbert, M.; Cormaci, M.; Furnari, G.; Kornprobst, J.M. Annual variation in composition and in vitro anti-HIV-1 activity of the sulfated glucuronogalactan from Schizymenia dubyi (Rhodophyta, Gigartinales). J. Appl. Phycol. 1996, 8, 155-161. [CrossRef]

46. Chen, Y.; Song, M.Y.; Wang, Y.X.; Xiong, W.; Zeng, L.; Zhang, S.B.; Xu, M.Y.; Du, H.X.; Liu, J.G.; Wang, D.Y.; et al. The anti-DHAV activities of Astragalus polysaccharide and its sulfate compared with those of BSRPS and its sulfate. Carbohydr. Polym. 2015, 117, 339-345. [CrossRef] [PubMed]

47. Yu, M.; Ji, Y.B.; Qi, Z.; Cui, D.; Xin, G.S.; Wang, B.; Cao, Y.; Wang, D.D. Anti-tumor activity of sulfated polysaccharides from Sargassum fusiforme. Saudi Pharm. J. 2017, 25, 464-468. [CrossRef] [PubMed]

48. Xie, J.H.; Wang, Z.J.; Shen, M.Y.; Nie, S.P.; Gong, B.; Li, H.S.; Zhao, Q.; Li, W.J.; Xie, M.Y. Sulfated modification, characterization and antioxidant activities of polysaccharide from Cyclocarya paliurus. Food Hydrocoll. 2016, 53, 7-15. [CrossRef]

49. Li, J.; Chi, Z.; Yu, L.; Jiang, F.; Liu, C. Sulfated modification, characterization, and antioxidant and moisture absorption/retention activities of a soluble neutral polysaccharide from Enteromorpha prolifera. Int. J. Biol. Macromol. 2017, 105, 1544-1553. [CrossRef] [PubMed] 
50. Dubois, M.; Gilles, K.A.; Hamilton, J.K.; Rebers, P.A.; Smith, F. Colorimetric method for determination of sugars and related substances. Anal. Chem. 1956, 28, 350-356. [CrossRef]

51. Bradford, M.M. Rapid and sensitive method for quantitation of microgram quantities of protein utilizing principle of protein-dye binding. Anal. Biochem. 1976, 72, 248-254. [CrossRef]

52. Kawai, Y.; Seno, N.; Anno, K. A modified method for chondrosulfatase assay. Anal. Biochem. 1969, 32, 314-321. [CrossRef]

53. Zhang, J.; Zhang, Q.; Wang, J.; Shi, X.; Zhang, Z. Analysis of the monosaccharide composition of fucoidan by precolumn derivation HPLC. Chin. J. Oceanol. Limn. 2009, 27, 578-582. [CrossRef]

54. Livak, K.J.; Schmittgen, T.D. Analysis of relative gene expression data using real-time quantitative PCR and the $2^{-\Delta \Delta C T}$ method. Methods 2001, 25, 402-408. [CrossRef] [PubMed]

55. Shandiz, S.A.S.; Khosravani, M.; Mohammadi, S.; Noorbazargan, H.; Mirzaie, A.; Inanlou, D.N.; Jalali, M.D.; Jouzaghkar, H.; Baghbani-Arani, F.; Keshavarz-Pakseresht, B. Evaluation of imatinib mesylate (Gleevec) on KAI1/CD82 gene expression in breast cancer MCF-7 cells using quantitative real-time PCR. Asian Pac. J. Trop. Biomed. 2016, 6, 159-163. [CrossRef]

(C) 2017 by the authors. Licensee MDPI, Basel, Switzerland. This article is an open access article distributed under the terms and conditions of the Creative Commons Attribution (CC BY) license (http:// creativecommons.org/licenses/by/4.0/). 